\title{
Medical Treatment of Cushing's Syndrome: Glucocorticoid Receptor Antagonists and Mifepristone
}

\author{
Frederic Castinetti Bernard Conte-Devolx Thierry Brue \\ Service d'endocrinologie, diabète et maladies métaboliques, et Centre de référence des maladies rares d'origine \\ hypophysaire DEFHY, Hôpital de la Timone, Marseille, France
}

\section{Key Words}

Cushing's disease $\cdot$ Anticortisolic drug $\cdot$ Ectopic ACTH

secretion · Adrenal carcinoma $\cdot$ Bilateral adrenal

hyperplasia $\cdot$ Glucocorticoid receptor antagonist

\begin{abstract}
Mifepristone is the first and only available glucocorticoid receptor antagonist. It was initially mainly considered as a socalled 'contragestive' pill due to its antiprogestin activity. In this review, we summarize the results of mifepristone reported in the literature as a treatment of Cushing's syndrome. Most of the patients were treated due to unsuccessful surgery and/or partially effective anticortisolic drugs. The majority of them presented a rapid decrease of clinical signs of hypercortisolism during the first month of treatment; about half experienced a reduction in their elevated blood pressure, and half of the diabetic patients presented improved blood glucose levels. Mifepristone treatment has 2 main drawbacks: (1) the blockade of glucocorticoid receptors leads to increased ACTH and cortisol levels, making it difficult to adapt the treatment and diagnose adrenal deficien$c y$, and (2) increased cortisol levels can also lead to severe hypokalemia. Follow-up of efficacy should only be clinical (weight, blood pressure, skin lesions) and biological (regular blood potassium sampling). Dose adjustment will be performed based on these parameters. The lack of a large avail-
\end{abstract}

able prospective cohort of patients on mifepristone, and the scarcity of data on its long-term effects, does not allow recommending it as a first-line drug in the treatment of hypercortisolism. However, as mifepristone is a rapidly effective drug, it can play a role in the management of hypercortisolism. The main indication is the partial efficacy or bad tolerance of other well-known anticortisolic drugs, either by replacement (bad tolerance, lack of effectiveness) or addition (multimodal approach) of mifepristone.

Copyright $\odot 2010$ S. Karger AG, Basel

\section{Introduction}

Cushing's syndrome can be caused by adrenal, pituitary or ectopic tumors. Surgery remains the first-line treatment, and can be followed by pituitary irradiation or bilateral adrenalectomy if necessary. Medical management remains, however, of major interest when surgery is impossible, in preparation for surgery, or when surgery is partially effective. The efficacy of usual anticortisolic drugs (ketoconazole, metyrapone, mitotane, etc.) is not constant and may be limited by their poor tolerance $[1,2]$. Mifepristone, a glucocorticoid receptor antagonist initially considered as a so-called 'contragestive' pill, may represent an alternative [3]. Our recent European collaborative retrospective study [3] allowed to discuss the po-

\section{KARGER}

Fax +41613061234 E-Mail karger@karger.ch www.karger.com
(C) 2010 S. Karger AG, Base

0028-3835/10/0925-0125\$26.00/0

Accessible online at:

www.karger.com/nen
Thierry Brue

Department of Endocrinology, Diabetes and Metabolic Diseases

Timone Hospital, 204, rue Saint-Pierre

FR-13385 Marseille Cedex 05 (France)

Tel. +33 4913855 05, Fax +33 4913845 42, E-Mail thierry.brue@ ap-hm.fr 
Fig. 1. Clinical picture of a patient before (left) and 6 months after (right) treatment with mifepristone for an ectopic ACTH syndrome. Note the decrease in upper body obesity and facial erythrosis after treatment.
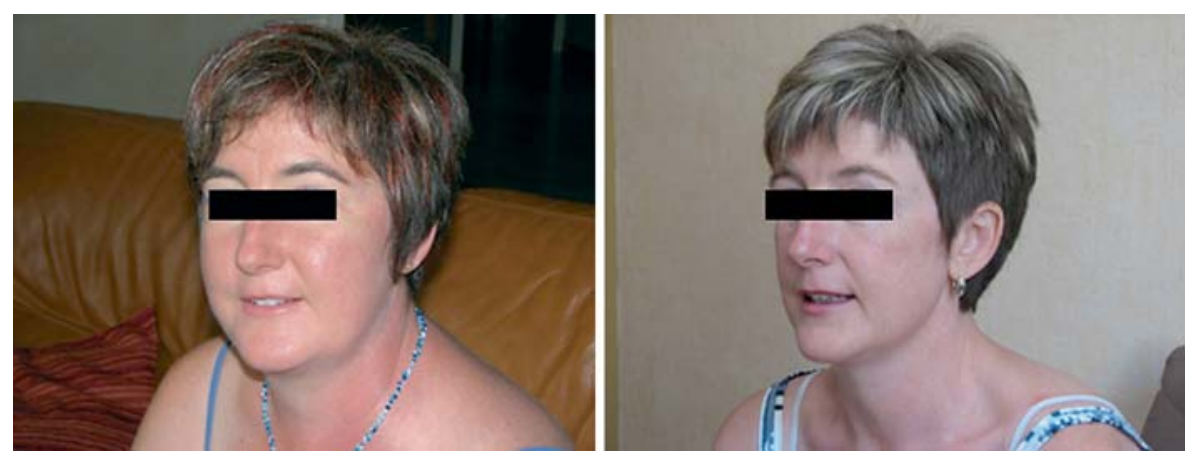

tential future role of this drug in the management of Cushing's syndrome. In the present review, we will mainly talk about mifepristone, as data about other potential glucocorticoid receptor antagonists are only experimental.

\section{Pharmaceutical Properties}

Mifepristone is a substituted 19-nor steroid compound chemically designated as $11 \beta$-[ $p$-(dimethylamino)phenyl]-17 $\beta$-hydroxy-17-(1-propynyl)estra-4,9-dien-3-one. It is the first and currently only available glucocorticoid receptor antagonist treatment [4]. Other glucocorticoid receptors are currently evaluated, but no clinical trial has been published to date [5]. Mifepristone has also a strong anti-progestin activity, and a weak anti-androgen activity: its relative binding affinity at the glucocorticoid receptor is more than three times that of dexamethasone and more than ten times that of cortisol; affinity at the progesterone receptor is more than twice that of progesterone, and affinity at the androgen receptor is less than one third that of testosterone. It does not bind to the estrogen receptor or the mineralocorticoid receptor. Following oral administration of a single dose of 400-600 mg, mifepristone is rapidly absorbed, with a peak plasma concentration occurring approximately 90 min after ingestion. Of note, in the absence of progesterone or cortisol, mifepristone can also act as a weak agonist $[5,6]$.

\section{Efficacy}

Mifepristone appears as a rapidly effective drug in controlling signs of hypercortisolism. To date, $37 \mathrm{pa}$ tients, mainly adults, have been reported in the literature as having received mifepristone for various etiologies of Cushing's syndrome (table 1) [7-16]. Most of them were treated due to unsuccessful surgery and partially effective or badly tolerated medical treatment. Up to $85 \%$ presented a decrease of their clinical signs of hypercortisolism (weight loss, improvement of skin signs) during the first month of mifepristone (fig. 1). About half experienced a reduction in their elevated blood pressure and half of the diabetic patients also presented improved blood glucose levels, sometimes leading to withdrawal of antidiabetic drugs. The majority of the patients have been treated for an advanced adrenal carcinoma, ectopic ACTH secretion or Cushing's disease.

\section{Adrenal Carcinoma}

Seventeen patients have been reported to date. In the majority of cases, mifepristone was given in advanced adrenal carcinomas after failed surgery, and lack of efficacy of classical anticortisolic drugs (including mitotane). Median duration of treatment was 3 months (range 0.25-9). Clinical signs of hypercortisolism improved in $76 \%$ of the cases during the first month of treatment. In our series, $60 \%$ of the patients presented improved blood pressure levels. Interestingly, one patient with severe psychosis had a drastic improvement of psychiatric signs in the first few days of mifepristone treatment.

\section{Ectopic ACTH Secretion}

Twelve patients have been treated with mifepristone after unsuccessful surgery or lack of identified tumor. Median duration of treatment was 5.5 months (range 0.3-18). All patients presented an improvement of their clinical signs. About half of them experienced decreased blood pressure levels. Severe psychosis signs improved in the first few days of mifepristone treatment in 1 patient. 
Table 1. Individual data of patients treated with mifepristone for adrenal carcinoma (patients 1-17), ectopic ACTH secretion (18-29), Cushing's disease (30-34) or other causes (35-37)

\begin{tabular}{|c|c|c|c|c|c|c|c|c|}
\hline $\begin{array}{l}\text { Patient } \\
\text { No. }\end{array}$ & $\begin{array}{l}\text { Sex/ } \\
\text { age }\end{array}$ & $\begin{array}{l}\text { Dose } \\
\text { mg/day }\end{array}$ & $\begin{array}{l}\text { Previous } \\
\text { treatments }\end{array}$ & $\begin{array}{l}\text { Duration } \\
\text { months }\end{array}$ & $\begin{array}{l}\text { High } \\
\mathrm{BP}\end{array}$ & $\begin{array}{l}\text { Hypoka- } \\
\text { lemia }\end{array}$ & $\begin{array}{l}\text { Adrenal } \\
\text { insufficiency }\end{array}$ & Diabetes \\
\hline 1 & $\mathrm{~F} / 45$ & $5-22 \mathrm{mg} / \mathrm{kg}$ & & 2 & & & & \\
\hline 2 & $\mathrm{~F} / 32$ & 400 & & 2 & & & & \\
\hline 3 & F/NA & $20-30 \mathrm{mg} / \mathrm{kg}$ & & 4 & & & & \\
\hline 4 & $\mathrm{M} / 62$ & 400 & & 9 & & & $\uparrow$ & \\
\hline 5 & $\mathrm{M} / 43$ & $400-800 \mathrm{mg}$ & & 0.5 & & & & \\
\hline 6 & $\mathrm{M} / 63$ & 1,000 & M & 6 & $\downarrow$ & $\leftrightarrow$ & & $\downarrow$ \\
\hline 7 & $\mathrm{~F} / 39$ & 400 & M & 2.5 & $\leftrightarrow$ & $\uparrow$ & & - \\
\hline 8 & $\mathrm{~F} / 52$ & $400-600$ & M & 3 & $\downarrow$ & $\uparrow$ & & - \\
\hline 9 & $\mathrm{~F} / 52$ & $400-600$ & M & 3 & $\downarrow$ & $\uparrow$ & & $\leftrightarrow$ \\
\hline 10 & $\mathrm{~F} / 45$ & $400-2,000$ & $\mathrm{M}+\mathrm{K}$ & 1 & - & $\uparrow$ & & - \\
\hline 11 & $\mathrm{~F} / 63$ & 600 & $\mathrm{M}+\mathrm{K}$ & 2 & $\leftrightarrow$ & - & $\uparrow$ & - \\
\hline 12 & $\mathrm{M} / 20$ & $600-1,200$ & $\mathrm{M}+\mathrm{K}$ & 1 & $\downarrow$ & $\uparrow$ & $\uparrow$ & $\leftrightarrow$ \\
\hline 13 & $\mathrm{~F} / 47$ & $400-1,200$ & $\mathrm{M}+\mathrm{K}$ & 2 & $\leftrightarrow$ & $\uparrow$ & & - \\
\hline 14 & $\mathrm{~F} / 38$ & $400-600$ & $\mathrm{M}+\mathrm{m}$ & 3 & - & - & & - \\
\hline 15 & $\mathrm{~F} / 44$ & $200-600$ & $\mathrm{M}+\mathrm{m}$ & 2 & - & - & & - \\
\hline 16 & $\mathrm{M} / 64$ & $200-400$ & $\mathrm{M}+\mathrm{m}$ & 1.5 & - & - & & - \\
\hline 17 & $\mathrm{M} / 52$ & 600 & $\mathrm{M}+\mathrm{E}$ & 0.25 & - & $\uparrow$ & & $\leftrightarrow$ \\
\hline 18 & $\mathrm{M} / 36$ & $5-22 \mathrm{mg} / \mathrm{kg}$ & & 10 & & & $\uparrow$ & \\
\hline 19 & $\mathrm{M} / 42$ & $5-22 \mathrm{mg} / \mathrm{kg}$ & & 12 & & & & \\
\hline 20 & $\mathrm{~F} / 63$ & $5-22 \mathrm{mg} / \mathrm{kg}$ & & 4 & & & $\uparrow$ & \\
\hline 21 & $\mathrm{~F} / 55$ & $5-22 \mathrm{mg} / \mathrm{kg}$ & & 2.5 & & & & \\
\hline 22 & $\mathrm{~F} / 46$ & $800-1,600$ & & 0.3 & & & & \\
\hline 23 & $\mathrm{M} / 25$ & $5-20 \mathrm{mg} / \mathrm{kg}$ & $\mathrm{m}+$ chemotherapy & 2.5 & $\downarrow$ & $\downarrow$ & & $\downarrow$ \\
\hline 24 & $\mathrm{~F} / 2$ & $75-300$ & none & 2 & $\downarrow$ & - & & $\downarrow$ \\
\hline 25 & $\mathrm{~F} / 46$ & 600 & chemotherapy & 2 & $\uparrow$ & $\uparrow$ & & $\downarrow$ \\
\hline 26 & $\mathrm{~F} / 37$ & 800 & chemotherapy & 10 & $\uparrow$ & $\uparrow$ & & - \\
\hline 27 & $\mathrm{M} / 55$ & $400-600$ & $\mathrm{E}+\mathrm{m}$ & 1 & $\downarrow$ & $\uparrow$ & & $\downarrow$ \\
\hline 28 & $\mathrm{~F} / 43$ & 600 & $\mathrm{~K}$ & 2 & $\uparrow$ & $\uparrow$ & & $\downarrow$ \\
\hline 29 & $\mathrm{~F} / 38$ & $400-800$ & $\mathrm{~K}$ & 18 & $\uparrow$ & $\uparrow$ & & - \\
\hline 30 & $\mathrm{M} / 45$ & $400-800$ & $\mathrm{~K}$ & 12 & - & - & & - \\
\hline 31 & $\mathrm{M} / 56$ & $600-1,200$ & $\mathrm{~K}$ & 24 & - & - & $\uparrow$ & - \\
\hline 32 & $\mathrm{~F} / 50$ & 600 & - & 0.5 & - & $\leftrightarrow$ & & - \\
\hline 33 & $\mathrm{~F} / 45$ & 600 & - & 3 & $\uparrow$ & $\uparrow$ & & - \\
\hline 34 & $\mathrm{M} / 51$ & $400-2,000$ & $\mathrm{~K}$ & 18 & $\leftrightarrow$ & $\uparrow$ & $\uparrow$ & - \\
\hline 35 & $\mathrm{~F} / 38$ & $5-22 \mathrm{mg} / \mathrm{kg}$ & - & 1.5 & & & & \\
\hline 36 & $\mathrm{~F} / 52$ & 600 & $\mathrm{~K}$ & 6 & - & $\leftrightarrow$ & & $\downarrow$ \\
\hline 37 & $\mathrm{~F} / 14$ & 400 & - & 8 & - & - & & - \\
\hline
\end{tabular}

Previous treatments are treatments administered before the start of mifepristone therapy: $\mathrm{M}=$ mitotane; $\mathrm{K}=$ ketoconazole; $\mathrm{m}=$ metyrapone; E = etomidate. High blood pressure (BP), hypokalemia, adrenal insufficiency and diabetes: $\downarrow=$ alleviation or improvement on mifepristone; $\uparrow=$ worsening or onset on mifepristone; $\leftrightarrow=$ unchanged on mifepristone; $-=$ absent before treatment, unchanged on mifepristone; blank space for patients $1-5=$ not available.

\section{Cushing's Disease}

Five patients have been treated to date because of the lack of pituitary adenoma visualized on MRI, failed surgery, bad tolerance to other anticortisolic drugs or partial efficacy of a radiosurgical procedure. Mean duration of treatment was 11 months (range $0.5-24$ ). All but one patient presented improved clinical signs. Again, 1 patient with severe psychosis had a drastic improvement of psychiatric signs in the first few days of mifepristone treatment. 
Of note, 1 patient has been treated for bilateral adrenal hyperplasia, and 2 for a likely benign adrenal adenoma (but the precise etiology is unclear). All of them experienced a rapid improvement of clinical signs of hypercortisolism during the first month of mifepristone treatment [10].

\section{Tolerance}

In Cushing's syndrome, hypokalemia is directly related to glucocorticoid excess as massive hypercortisolemia leads to incomplete renal inactivation of cortisol by $11 \beta$-dehydrogenase, and hence mineralocorticoid excess. Mifepristone requires careful medical attention and a close follow-up of this specific point. As mifepristone blocks only glucocorticoid action, the mineralocorticoid activity of cortisol excess is not affected by mifepristone treatment, thus leading to hypokalemia. On the contrary, mifepristone may lead to an increase of plasma ACTH and consecutively of cortisol levels in some patients with Cushing's syndrome, particularly with Cushing's disease due to alterations in negative feedback (a mechanism of hypokalemia similar to the one observed in Cushing's syndrome without treatment) [5]. Mifepristone-induced hypokalemia was observed in one third of the $37 \mathrm{Cush}$ ing's patients reported to date. In a few cases, hypokalemia was very severe, requiring high doses of oral and intravenous potassium, and intensive anti-aldosterone treatment. Severe hypokalemia should thus represent a contraindication for this treatment and potassium levels need to be carefully monitored. The same mechanism can induce increased blood pressure levels, which was observed in 5 patients, despite an improvement of clinical signs of hypercortisolism. The ideal treatment remains high dose anti-aldosterone treatment: there is no need for a systematic prescription at the onset of mifepristone, except in case of low-normal hypokalemia.

Moreover, the lack of available biological parameters of follow-up on treatment obviously represents a limitation for the use of mifepristone. Signs suggestive of adrenal insufficiency have been reported in $16 \%$ of the $37 \mathrm{pa}-$ tients reported to date. The blockade of glucocorticoid receptors does not allow determining the efficacy of the drug by measuring ACTH and cortisol levels that are increased by mifepristone treatment. However, this low rate of adrenal deficiency is puzzling taking into account the mechanism of action of mifepristone: it is probably due to a partial blockade of glucocorticoid receptor antagonists, or a weak agonist effect of the drug [5]. Manage- ment of adrenal deficiency is also difficult: hydrocortisone is not effective; dexamethasone (1 $\mathrm{mg}$ for $400 \mathrm{mg}$ of mifepristone) should be given during $48 \mathrm{~h}$ in parallel with mifepristone withdrawal. Mifepristone can be re-initiated at a lower dose after the treatment of adrenal deficiency [17].

Antiprogestin effects are also important to notice as they can induce an endometrial hyperplasia (relative hyperestrogenia). Three patients have been reported in the literature with this adverse effect [14]. Pelvic ultrasonography should be performed yearly in every woman before menopause.

\section{Dose and Follow-Up}

Mifepristone should be initiated at a low dose (200$400 \mathrm{mg} /$ day), and increased every 2-4 weeks based on clinical efficacy and tolerance. The maximal dose given should be around 400-800 mg/day. Increasing the dose up to $1,000 \mathrm{mg} /$ day is usually not necessary, and increases the risk of adverse effects. However, increase in the dose of mifepristone could be performed more rapidly in case of severe signs of psychosis [10].

Follow-up of efficacy, and dose adjustments should mainly rely on clinical and necessarily imperfect parameters like weight, blood pressure or skin lesions. ACTH and cortisol levels will be increased, and do not represent a good marker of the efficacy of the drug. Adrenal deficiency should be suspected in case of weakness, fatigue, nausea, vomiting, and hypoglycemic episodes [10].

As mentioned previously, only a limited number of patients have been treated long-term with mifepristone, probably because more than a third of patients reported to date presented an advanced adrenal carcinoma. If long-term treatment is considered, pelvic ultrasonography should be performed at least yearly in nonmenopausal women. No specific adverse effects other than the ones seen at short-term have been reported.

\section{Pros and Cons in Comparison with Other Anticortisolic Drugs}

The potential risks and benefits of mifepristone have to be weighed against alternative treatment options. The majority of other anticortisolic drugs have the major advantage to induce decreased cortisol levels: they are thus easier to follow (regular measures of plasma cortisol levels), whereas during mifepristone, cortisol concentration 
provides no guidance for treatment. However, the other anticortisolic drugs classically expose patients to frequent and/or severe side effects without superior efficacy. Ketoconazole has been reported to induce serious and life-threatening hepatotoxicity, although this side effect is rare (1/15,000 cases). Moreover, ketoconazole is no longer available in some European countries (e.g. Germany) [2]. Metyrapone, an inhibitor of $11 \beta$-hydroxylase, is not easily available in several European countries and may also be associated with significant side effects [18]. Etomidate can only be used intravenously and, therefore, should be reserved for severe cases [19]. The use of mitotane can be difficult due to a narrow therapeutic window, and overall bad tolerance (gastrointestinal and neurotoxic effects). Moreover, most of these treatments are not as rapidly effective as mifepristone. This is particularly true for mitotane, which requires several weeks before being fully effective $[20,21]$.

Thus, treatment with mifepristone may be of significant value in the medical treatment of Cushing's syndrome in a high percentage of cases. Its place must be defined in regards of the severity of the disease. Due to the low number of patients reported, mifepristone cannot be recommended as a first-line treatment, even in comparison with more classical anticortisolic drugs. Mifepristone should be reserved to patients with lack of/partial efficacy and/or bad tolerance of well-known therapeutic procedures, i.e. surgery, radiotherapy and other anticortisolic drugs. Of note, mifepristone can be added to other anticortisolic drugs, as they have different mech- anisms of actions. In this case, follow-up (mainly in terms of signs of adrenal deficiency and potassium levels) should be very strict.

\section{Conclusion}

Mifepristone represents a rapidly effective treatment to control signs of hypercortisolism with the main drawback of the impossibility to follow blood cortisol levels. The risk of severe hypokalemia needs to be closely monitored and further limits its widespread use. Despite these promising results, the lack of a large available prospective cohort of patients on mifepristone, and the scarcity of data on its long-term effects, does not allow recommending it as a first-line drug in the treatment of hypercortisolism. However, as mifepristone is a rapidly effective drug, its main indication is the partial efficacy or bad tolerance of other well-known anticortisolic drugs especially in patients with psychiatric signs of hypercortisolism. Only a limited number of patients have been treated longterm with mifepristone and if long-term treatment is considered, one should keep in mind the anti-progestin activity of mifepristone, as this can lead to endometrial hyperplasia.

\section{Disclosure Statement}

The authors have nothing to disclose.

\section{References}

1 Biller BM, Grossman AB, Stewart PM, Melmed S, Bertagna X, Bertherat J, Buchfelder M, Colao A, Hermus AR, Hofland LJ, Klibanski A, Lacroix A, Lindsay JR, NewellPrice J, Nieman LK, Petersenn S, Sonino N, Stalla GK, Swearingen B, Vance ML, Wass JA, Boscaro M: Treatment of adrenocorticotropin-dependent Cushing's syndrome: a consensus statement. J Clin Endocrinol Metab 2008;93:2454-2462

2 Castinetti F, Morange I, Jaquet P, Conte-Devolx B, Brue T: Ketoconazole revisited: a preoperative or postoperative treatment in Cushing's disease. Eur J Endocrinol 2008; 158:91-99.

-3 Johanssen S, Allolio B: Mifepristone (ru 486) in Cushing's syndrome. Eur J Endocrinol 2007; 157:561-569.
Bertagna X, Bertagna C, Luton JP, Husson JM, Girard F: The new steroid analog ru 486 inhibits glucocorticoid action in man. J Clin Endocrinol Metab 1984;59:25-28.

5 McMaster A, Ray DW: Drug insight: selective agonists and antagonists of the glucocorticoid receptor. Nat Clin Pract 2008;4: 91-101.

6 6 Miller JW, Crapo L: The medical treatment of Cushing's syndrome. Endocr Rev 1993;14: 443-458.

7 Beaufrere B, de Parscau L, Chatelain P, Morel Y, Aguercif M, Francois R: Ru 486 administration in a child with Cushing's syndrome. Lancet 1987;ii:217.

-8 Bilgin YM, van der Wiel HE, Fischer HR, De Herder WW: Treatment of severe psychosis due to ectopic Cushing's syndrome. J Endocrinol Invest 2007;30:776-779.
9 Cassier PA, Abou-Amara-Olivieri S, Artru P, Lapalus MG, Riou JP, Lombard-Bohas C: Mifepristone for ectopic acth secretion in metastatic endocrine carcinomas: report of two cases. Eur J Endocrinol 2008;158:935938.

10 Castinetti F, Fassnacht M, Johanssen S, Terzolo M, Bouchard P, Chanson P, Do Cao C, Morange I, Pico A, Ouzounian S, Young J, Hahner S, Brue T, Allolio B, Conte-Devolx B: Merits and pitfalls of mifepristone in Cushing's syndrome. Eur J Endocrinol 2009; 160: 1003-1010.

-11 Chu JW, Matthias DF, Belanoff J, Schatzberg A, Hoffman AR, Feldman D: Successful long-term treatment of refractory cushing's disease with high-dose mifepristone (ru 486). J Clin Endocrinol Metab 2001;86:35683573 
12 Contreras P: Adrenal cancer: tumor regression with ketoconazole or mifepristone (ru 486): in vivo and in vitro evidence supporting tumoral hormone dependency. Proc 69th Ann Endocrine Society Meeting, Indianapolis, 1987, p 23.

$\checkmark 13$ Donckier JE, Michel LA, Berbinschi A, De Coster PM, De Plaen JF, Ketelslegers JM, Buysschaert M: Late recurrence of operated adrenocortical carcinoma: atrial natriuretic factor before and after treatment with mitotane. Surgery 1989;105:690-692.

-14 Newfield RS, Spitz IM, Isacson C, New MI: Long-term mifepristone (ru486) therapy resulting in massive benign endometrial hyperplasia. Clin Endocrinol 2001;54:399404
15 Nieman LK, Chrousos GP, Kellner C, Spitz IM, Nisula BC, Cutler GB, Merriam GR, Bardin CW, Loriaux DL: Successful treatment of cushing's syndrome with the glucocorticoid antagonist ru 486. J Clin Endocrinol Metab 1985;61:536-540.

16 van der Lely AJ, Foeken K, van der Mast RC, Lamberts SW: Rapid reversal of acute psychosis in the Cushing syndrome with the cortisol-receptor antagonist mifepristone (ru 486). Ann Intern Med 1991;114:143-144.

17 Raux-Demay MC, Pierret T, Bouvier d'Yvoire M, Bertagna X, Girard F: Transient inhibition of ru 486 antiglucocorticoid action by dexamethasone. J Clin Endocrinol Metab 1990;70:230-233.

18 Verhelst JA, Trainer PJ, Howlett TA, Perry L, Rees LH, Grossman AB, Wass JA, Besser GM: Short and long-term responses to metyrapone in the medical management of 91 patients with Cushing's syndrome. Clin Endocrinol 1991;35:169-178.
9 Schulte HM, Benker G, Reinwein D, Sippell WG, Allolio B: Infusion of low dose etomidate: correction of hypercortisolemia in patients with Cushing's syndrome and doseresponse relationship in normal subjects. J Clin Endocrinol Metab 1990;70:1426-1430.

20 Hahner S, Fassnacht M: Mitotane for adrenocortical carcinoma treatment. Curr Opin Investig Drugs 2005;6:386-394.

21 Terzolo M, Angeli A, Fassnacht M, et al: Adjuvant mitotane treatment for adrenocortical carcinoma. N Engl J Med 2007;356:23722380 . 